\title{
Dociekania
}

\section{„Byłem raz w kinie..." - Karol Irzykowski wobec kina popularnego w latach 20. XX wieku}

Weronika Szulik

TEKSTY DRUGIE 2018, NR 5, S. 212-229

DOI: $10.18318 /$ td. $2018.5 \cdot 13$

$D$ ziesiąta Muza Karola Irzykowskiego (1924) jako pionierskie ujęcie teorii kina niemego wydaje się obecnie tematem wyczerpanym i zamkniętym. Kwestii filmu jako „obcowania człowieka z materią” oraz „Królestwa Ruchu” poświęcono kilka artykułów ${ }^{1}$ oraz trzy duże monografie. W każdej z dotychczasowych prac Irzykowski pozostaje przede wszystkim teoretykiem kina - Aleksander Kumor potraktował propozycję Irzykowskiego z perspektywy strukturalistycznej², Maria Gołębiewska jako punkt wyjścia do namysłu nad filozoficzną i antropologiczną myślą

1 Wśród opracowań znajdują się na przykład: K.T. Toeplitz Wstęp, w: K. Irzykowski Dziesiąta Muza, Filmowa Agencja Wydawnicza, Warszawa 1957; J. Bocheńska Polska myśl filmowa do 1939 roku, Ossolineum, Wrocław-Warszawa-Kraków 1974; W. Świdziński Karola Irzykowskiego poglądy na komedię filmową. Poniżenie i triumf materii w Królestwie Ruchu, "Kwartalnik Filmowy" $2011 \mathrm{nr} 72$.

2 Zob. A. Kumor Karol Irzykowski. Teoretyk filmu, Wydawnictwa Artystyczne i Filmowe, Warszawa 1965, s. 7.

\section{Weronika Szulik}

- doktorantka w Zakładzie Literatury i Kultury Drugiej Połowy XIX wieku, w Instytucie Literatury Polskiej Wydziału Polonistyki UW. Publikowała w „Przeglądzie Humanistycznym", "Pleografie" oraz „Pamiętniku Literackim". Laureatka konkursu dla studentów i doktorantów Identitas. Interesuje się polskim modernizmem na przełomie XIX i XX wieku, kulturą popularną, głównie filmem niemym. 
krytyka³, a Elizabeth Nazarian skupiła się na opisie jego „teoretyzowania”, czyli procesie myślenia o filmie i kinie ${ }^{4}$.

Celem niniejszego artykułu będzie próba ukazania Irzykowskiego jako aktywnego uczestnika rodzącej się kultury wizualnej i zerwania z utrwalonym wizerunkiem chłodnego analityka ${ }^{5}$. Autor Beniaminka brał bowiem udział w procesie rozwoju kina nie tylko jako diagnosta nowej sytuacji kultury ${ }^{6}$ czy uczestnik dyskusji teoretycznej w kraju i za granicą ${ }^{7}$, lecz także jako bywalec pokazów filmowych oraz krytyk i recenzent zaangażowany w spory wokół produkcji kinowej. Zbadanie tej kwestii z tego punktu widzenia jest o tyle interesujące, o ile pokazuje, jak teoria Irzykowskiego wyrasta z jego namysłu nad widzem i kinem popularnym.

Cennym materiałem do zbadania tej kwestii okazały się - dotąd traktowane marginesowo - recenzje filmowe publikowane przez Irzykowskiego w latach 1924-1925 w „Wiadomościach Literackich”. W piśmie poświęconym głównie literaturze rubryka filmowa, ukazująca się nieregularne i umieszczana przeważnie na końcu numeru, służyła raczej do celów informacyjnych i reklamowych. Dopiero w latach 30. zaczęto umieszczać tam dłuższe artykuły, m.in. popularnej wówczas krytyczki Stefanii Zahorskiej oraz publikować, powstały z jej inicjatywy, dodatek „Światło na Ekran”.

Irzykowski przejął Kurier kinowy od Anatola Sterna już po premierze Dziesiatej Muzyi,jak pisał,,zgrzeczności, ze słabości, ostatecznie dla zarobku"10. Wypowiedź sprawia wrażenie jednej z prowokacji charakterystycznych dla krytyka, jednak wzestawieniuzwnioskami Barbary Gierszewskiejo prasiebranżowej, uprawiającej

3 Zob. M. Gołębiewska Irzykowski. Rzeczywistość i przedstawienie - o tezach filozoficznych Karola Irzykowskiego, Instytut Filozofii i Socjologii PAN, Warszawa 2006, s. 14.

4 Zob. E. Nazarian The Tenth Muse. Karol Irzykowski and Early Film Theory, Lap Lambert, Saarbrücken 2011, s. 4.

5 Na konieczność podobnego ujęcia wskazywała niedawno Sylwia Kołos O sile anachronizmu, czyli „X Muza" Karola Irzykowskiego wobec nowej historii kina, w: Świat idei i lektur - twórczość Karola Irzykowskiego, red. H. Ratuszna, Wydawnictwo Naukowe UMK, Toruń 2016, s. 124.

6 Zob. M. Gołębiewska Irzykowski. Rzeczywistość i przedstawienie, s. 248-267.

7 Zob. E. Nazarian The Tenth Muse..., s. 6.

8 Oprócz recenzji w tym czasopiśmie Irzykowski opublikował także opinię o Wschodzie słońca F.W. Murnaua („Robotnik” 1928) oraz o filmie Turksib Victora A. Turina („Nasz Przegląd” 1937).

9 Zob. M. Szpakowska „Wiadomości Literackie” prawie dla wszystkich, W.A.B., Warszawa 2012, s. 167.

10 K. Irzykowski Wywiad na księżycu Karola Irzykowskiego z samym sobq , "Wiadomości Literackie" $1925 \mathrm{nr}$ 5, s. 1. 
na swoich łamach głównie płatną kryptoreklamę", można wysnuć przypuszczenie, że Irzykowski ironicznym komentarzem opatrzył dobrze znany sobie ówczesny rynek kultury, na którym krytyk byłjuż nie „znawcą idei”,lecz,ekspertem w ocenie towaru"12.

W ciągu niemal dwóch lat Irzykowski obejrzał sześćdziesiąt sześć filmów i napisał dwadzieścia siedem recenzji. Lata 1924 i 1925 w kinach warszawskich obfitowały w produkcje amerykańskie i niemieckie, dopiero na trzecim miejscu francuskie. Lista filmów interesujących Irzykowskiego odzwierciedla ten stan - duża liczba zrecenzowanych przez niego filmów to produkcje hollywoodzkie oraz największe premiery kinematografii niemieckiej i francuskiej.Wśród nich znalazło się Czterechjeźdźców apokalipsy Rexa Ingrama, Dziesięcioro przykazań Cecila de Mille'a, komedie Charliego Chaplina.Z niemieckiego repertuaru pojawiły się na przykład Nibelungi Fritza Langa. Najchętniej Irzykowski wybierał się na filmy komediowe czy sensacyjne, ciekawily go także adaptacje literatury, mimo że zwykle nie oceniał ich pozytywnie. W drugiej połowie 1925 roku w warszawskich kinach zaczął się okres repertuarowej monotonii - Wojciech Świdziński zasugerował,że mógł to być jeden z powodów rezygnacji Irzykowskiego z prowadzenia rubryki kinowej ${ }^{13}$. Sam krytyk, tłumacząc swoją decyzję w artykule Chwalcom lichego towaru w odpowiedzi, dał do zrozumienia, że po prostu wypełnił założoną wcześniej misję zderzenia swoich poglądów z rzeczywistością produkcji kinowej [zob. DM: 436]. To wyznanie wydaje się nie do przecenienia: jeśli współpraca z „Wiadomościami Literackimi” miała Irzykowskiemu zapewnić możliwość sprawdzenia teorii zawartej w Dziesiątej Muzie, to recenzje, które nie tylko dopełniały książkę, ale również nierzadko wprost korygowały jej tezy, były dojrzałą formą jego myśli o kinie i filmie.

\section{„Byłem raz w kinie..."14 - Karol Irzykowski jako widz}

Jeszcze przed I wojną światową autor Dziesiątej Muzy uczestniczył w pokazach kinematograficznych łączonych z przedstawieniami

11 Zob. B. Gierszewska Czasopiśmiennictwo filmowe w Polsce do 1939 roku, Wyższa Szkoła Pedagogiczna im. Jana Kochanowskiego, Kielce 1995, s. 238. W. Świdziński Co było grane? Film zagraniczny w Polsce w latach 1918-1929 na przykładzie Warszawy, Instytut Sztuki PAN, Warszawa 2015, s. 169.

14 K. Irzykowski Dziesiq̨ta Muza oraz Pomniejsze pisma filmowe, Wydawnictwo Literackie, Kraków 1982, s. 18. Dalej w tekście głównym jako DM. 
cyrkowymi ${ }^{15}$. Te niesamowite, „żywe” obrazy zmieniające się na oczach widza mogły dać asumpt do pierwszego sformułowania tezy, że kino to przede wszystkim Królestwo Ruchu. Artykuł, w którym Irzykowski pisał o filmie jako „pieśni ruchu” [zob. DM: 18], czyli Śmierć kinematografu? (1913), został w całości przedrukowany w Dziesiątej Muzie jako rozdział pierwszy, niejako wprowadzający w tematykę książki. W tej edytorskiej decyzji widzę świadectwo rozumienia, że kino, w swoim technicznym rozwoju, ewoluowało, nigdy nie stawało się czymś radykalnie innym, szczególnie w czasie, kiedy pokazy kinematograficzne zaczęły przybierać formę narracyjną ${ }^{16}$. Tak więc Dziesiąta Muza była rozwinięciem i przedłużeniem refleksji zrodzonej bezpośrednio z oglądania "ruchomych obrazów”, czyli z żywego doświadczenia ${ }^{17}$.

Irzykowski jako widz to erudyta, dla którego rozrywka była zmysłową przyjemnością oraz intelektualną przygodą, odkrywaniem zjawisk i pojęć na nowo. Ponadto rozpatrywał on film na równi z innymi dziedzinami działalności człowieka, pisał, że „filmu zbyt głupiego wytrzymać nie można, tak samo jak trudno przeczytać do końca zbyt głupią książkę" [DM: 193]. Krytyk podchodził do kina bez uprzedzeń, ale i z wymaganiami kompetentnego uczestnika kultury. W jego recenzjach mało jest osobistych sądów, głównie skupia się on na konfrontowaniu filmów ze swoją teorią: dobry film to ten skonstruowany na jej zasadach. Jałowe byłoby więc oddzielanie prywatnych praktyk i upodobań autora Dziesiątej Muzy jako widza kinowego od jego pracy krytyka czy teoretyka, gdyż to, co zainteresowało w kinie teoretyka, jednocześnie sprawiało przyjemność widzowi. Mimo to można podjąć próbę scharakteryzowania Irzykowskiego jako widza - tego, który wybiera, co zobaczy $\mathrm{z}$ dostępnego repertuaru, i tego, który nie tylko ogląda filmy i o nich pisze,

15 Irzykowski poświęcił rozdział na omówienie związków kina z cyrkiem [zob. DM: 72-77]. Więcej o nowym typie kultury i odbiorcy końca XIX wieku pisała Małgorzata Hendrykowska - zob. Śladami tamtych cieni. Film w kulturze polskiej przełomu stuleci 1895-1914, Book Service, Poznań 1993, s. 67-68.

16 Łukasz Biskupski, za Tomem Gunningiem, pisał: „Mniej więcej pomiędzy 1907 rokiem a I wojną światową doszło do ukształtowania kultury filmowej, której wiele elementów utrzymało się przez większość XX wieku, a niektóre istnieją do dziś" - Ł. Biskupski Miasto atrakcji. Narodziny kultury masowej na przełomie XIX iXX wieku [MOBI], Warszawa 2013, loc 3218.

17 Obecnie w badaniach wraca się do początków kina, by opisać je jako fenomen kultury wizualnej, a w jego rozwoju widząc raczej ewolucję od maszyny rejestrującej do narracyjnego medium. O "kinie atrakcji” w tym kontekście jako pierwszy pisał Tom Gunning The Cinema of Attraction: Early Film, Its Spectator and the Avant-Garde, „Wide Angle” 1986 No. 3/4. Tematem tym zajmował się także wspólnie z André Gaudreaultem. 
ale również uczestniczy w narodzinach nowego typu publiczności, nowego sposobu mówienia o sztuce-produkcie.

Takim dynamicznie rozwijającym się wątkiem w kulturze lat 20. okazuje się kultura popularna. Irzykowski nie tylko dowartościowywał to, co uważane było za niemądrą rozrywkę, czyli film rysunkowy, lecz także uznał go za „film przyszłości” [zob. DM: 256]. Na kartach Dziesiątej Muzy znaleźć można przykład scenariusza filmu rysunkowego jego autorstwa: Miłośćżywiołów [zob. DM: 84-85].W II Rzeczypospolitej popularnością cieszyły się raczej rodzime aktorskie filmy melodramatyczne, będące bladym odbiciem systemu gwiazd ${ }^{18}$ na Zachodzie ${ }^{19}$. Krytyk zdecydowanie się od nich dystansował jako obrazów niespełniających założeń jego teorii, jednocześnie jednak, kiedy podkreślał, że kinu polskiemu potrzebna była jego osoba [zob. DM: 504], wydaje się, że chciał ratować kiepski film aktorski, jako gatunek najlepiej trafiający do szerokiej publiczności. To ten rodzaj inspirował masy i na nie wpływał.

Irzykowski nie ukrywał osobistego wyboru ocenianego repertuaru - mówił, jakie filmy chętnie oglądał, a jakie omijał. Pisał: „gdy na tych «fotosach» widzę np. morze, statek, wieżę, konie - mnie zaraz to ciągnie, obiecuje mi «prawdziwe kino»..." [DM: 393]. Jego faworytami w latach 20. bez wątpienia były filmy sensacyjne (również komediowe) oraz fantastyczne, a więc trikowe, które dawały wiele pretekstów do wykorzystania ruchu na ekranie. Zdradzał, że w kinie nudził go nachalny montaż, czyli „metoda siekaniny” rozdrabniająca fabułę; także zbyt dokładne bezpośrednie ilustrowanie obrazem napisów; stereotypowość filmu aktorskiego, którego scenariusz opierano na schematach literackich [zob. DM: 208-209]. Irzykowski, pisząc o dobrym filmie, miał na myśli przede wszystkim film przemyślany treściowo i formalnie, ale też ciekawy, rozrywkowy. Według niego do kina nie chodziło się przecież dla wrażeń artystycznych, lecz głównie, by zobaczyć coś nowego, rzeczy cudowne, niemożliwe do spełnienia w rzeczywistości [zob. DM: 37 i 75].

Uwagi Irzykowskiego na temat wykonania filmów pochodziły z doświadczenia i perspektywy widza. Przykładowo, nie zwracał on uwagi na rolę kamery, wolał plan pełny, na którym ruch stawał się lepiej widoczny jako łącznik między człowiekiem a materią. Jednocześnie spokojny montaż i minimalna

Chodzi o "star system": strategię promocji filmu przy pomocy popularności aktorów i aktorek, J. Gaines, Star system, w: Encyclopedia of early cinema, ed. by R. Abel, Routledge, London 2005; T. Lubelski i in. Kino nieme, Universitas, Kraków 2009, s. 179.

19 Zob. A. Madej Mitologie i konwencje. O polskim kinie fabularnym dwudziestolecia międzywojennego, Universitas, Kraków 1994, s. 73. 
praca kamery były po prostu dużo przyjemniejsze w odbiorze, widz łatwiej mógł obrać perspektywę „soczewki”"20. W kinie popularnym publiczność miała utożsamić się z jednym punktem widzenia, a wręcz przyjąć go za swój własny. Wtedy dużo skuteczniej można było przekazać jej wartości, przykładowo edukacyjne.

Wydaje się, że tym, co uwodziło Irzykowskiego w popularnych gatunkach jako takich (bez względu na medium), była ich aktualność - w przypadku sensacyjnych byłoby to połączenie intelektu i siły fizycznej w postaci detektywa, ,nowoczesnego rycerza”, a nawet wartka akcja jako czynnik zaciekawiający czytelnika treściami lektury ${ }^{21}$.W fantastyce docenił wyjście nowoczesnego człowieka naprzeciw przyszłości, marzenie o niej i obawy z nią związane. Warto nadmienić, że zarówno w przypadku literatury popularnej, jak i filmu Irzykowski kierował się także kategorią smaku, gustu. Dobry film niekoniecznie musiał spełniać artystyczne założenia Dziesiątej Muzy, wystarczyło, że jego twórcy w pogoni za uwagą odbiorcy szukali wyważonych środków wyrazu, a także nowych, niewidzianych do tej pory efektów. Dynamiczne obrazy kinowe oraz kinematograf jako wynalazek przyszłości okazały się idealnym medium dla tych cech sensacji i fantastyki. Przykładowo film trikowy Maks Linder w zamku duchów Irzykowski określił jako szczyt twórczości reżysera Abla Gance'a - sceny m.in. „wprowadzają w regiony niesamowitości” [zob. DM: 282]. Zaskakują i zachwycają jednocześnie. Szczególną atencją Irzykowskiego cieszył się film Bustera Keatona Rozkosze gościnności - oprócz podziwu dla sceny podróży koleją żelazną, która byłaby „kopalnią motywów kinowych” [zob. DM: 328], krytyk przyznawał, że obraz pod względem dramatycznym może być porównany do sztuki teatralnej [zob. DM: 329]. Autor Dziesiatej Muzy bardzo cenił także komedie z Chaplinem² - w recenzji filmu Brzdacc, który notabene uważał za prawdopodobnie zbyt dobry dla zwykłej publiczności, również zwracał uwagę na element dramatyczny: tramp swoją sztuką filmową "chwytał za serce" [zob. DM: 409, 410].

W pismach Irzykowskiego pojawiła się więc nowa kategoria oceniania dzieł kultury - emocja, zachwyt i wzruszenie. Wydaje się, jakby efekty

20 Kwestię percepcji widza w teorii Irzykowskiego podkreślała Nazarian The Tenth Muse..., s. 114.

Zob. K. Irzykowski Czyn i słowo oraz Fryderyk Hebbel jako poeta konieczności. Lemiesz i szpada przed sqdem publicznym. Prolegomena do charakterologii, Wydawnictwo Literackie, Kraków 1980, s. 280-282. 
dramatyczne wpływające na Irzykowskiego były uzyskiwane przy okazji, wypływały wprost z głównego przedmiotu zainteresowania krytyka, czyli z tematu ruchu. Tym samym były szczere, bo nie obliczone czy zaplanowane. Szczerość pozostawała bardzo ważną kategorią dla Irzykowskiego od czasów manifestu Czym jest Horla? (1896), w którym postulował pierwotne, bezpośrednie doświadczenie twórcy jako materiał dla dzieła sztuki ${ }^{23}$. Już tutaj rozróżniał poezję od literatury - spowiedź od konwencji. Tę młodopolską kategorię Irzykowski rozumiał w bliskim sąsiedztwie pojęcia „prawdy jako wirującej kuli"24, która była kategorią pomagającą w wyrażeniu przez artystę chaosu rzeczywistości i doświadczeń, różnych przejawów owej prawdy nierzadko sobie przeczących. Jak pisała Katarzyna Sadkowska: „wrażenie jest silniejsze, jeśli jest skomplikowane, podszyte dysonansem, wzmocnione przez swoje przeciwieństwo" 25 . Tak więc to, co ujawniało różne strony jednego zjawiska, było bardziej wartościowe od tego, co zbudowane z premedytacja, by wywołać konkretne, starannie obliczone uczucie w czytelniku. Analogicznie i w widzu kinowym.

Być może dlatego krytyk wolał „jeden dobry film sensacyjny od całej konewki łez amerykańskich" [DM: 247] - jako widz nie lubił być manipulowany, oszukiwany, chciał odczuwać, lecz indywidualnie, zgodnie ze swoją wrażliwością.

Co ciekawe, mimo postulatu, by krytyk zawsze kierował się w opiniach ustaloną metodą, w recenzji polskiego filmu Rywale (reż. Henryk Szaro) pojawiła się wzmianka o szczególnej sympatii, jaką autor Dziesiątej Muzy żywił do produkcji. W filmie występował motyw warszawskich tramwajów, co obudziło wspomnienia Irzykowskiego:

och, kiedy w Warszawie był taki brak tramwajów, kiedy na platformach panował potworny ścisk, wówczas przeżywałem nieraz tantalowe męki p. Fertnera, który nie może się nigdzie docisnąć. Zawsze było tak, że na ostatnim stopniu stał tyłem do mnie obrócony mężczyzna [...]. Według stylu kinowej farsy trzeba go było raz kolanem wyrżnąć w to miejsce, aby czar przełamać. [DM: 360-361]

Zob. K. Irzykowski Nowele, Wydawnictwo Literackie, Kraków 1979, s. 83. 
W przytoczonym cytacie Irzykowski pośrednio przyznaje, że dzięki filmowi jego fantazje zostały w pewien sposób zrealizowane. Można to wyznanie przyrównać do tego, co według Edgara Morina było charakterystycznym dla kina procesem „przyoblekania subiektywnego w ciało". To, co stanowi domenę uczucia, marzenia czy wspomnienia z dzieciństwa, podczas seansu miałoby uobecniać się i zobiektywizowaćéc. W przypadku Irzykowskiego, oglądającego Brzdąca lub Rywali, wzruszającego się czy wspominającego i sympatyzującego z filmem, można zaobserwować pojawienie się napięcia między postawami obserwującego i uczestniczącego - z jednej strony autor Dziesiątej Muzy oglądał film z pozycji zewnętrznej i nastawionej na jego ocenę, z drugiej strony znajdował się wewnątrz tego układu: był jednocześnie widzem, uczestnikiem spektaklu wyobraźni.,„Jest to nieustanny dialektyczny spór toczący się w łonie zadziwiającego kompleksu realności i nierealności. Rzeczywistość postrzegania pochłania magiczno-uczuciową nierealność, ale ona sama zostaje odrealniona w wizji estetycznej..."27 - skoro konflikt między racjonalnym spojrzeniem na film z zewnątrz układu i oglądanie go z pozycji widza identyfikującego się uczuciowo z obrazem jest wpisany w medium, być może w tym przypadku roli widza i krytyka z samej zasady nie można rozdzielić: jest to uzupełnianie się zachwytu i intelektualnego wyabstrahowania.Trzeba jednak wspomnieć, że przytoczone wcześniej dwa świadectwa bardziej naiwnego, „emocjonalnego” oglądania filmów przez Irzykowskiego to w zasadzie jedyne takie osobiste wyznania w jego pismach - nawet dziennik i listy krytyka jedynie wzmiankują kino, zazwyczaj w kontekście Dziesiątej Muzy i rozczarowania niezrozumieniem jej założeń przez recenzentów ${ }^{\mathbf{2 8}}$.

W latach 30. Irzykowski wyraził nieufność w stosunku do wynalazku dźwiękowca oraz przekonanie, że dźwięk zabił nie tylko film niemy, ale również film w ogóle ${ }^{29}$, jednak sugestywna pozostaje wciąż jego formuła, że film niemy „żyje, żyje jeszcze wewnątrz dzisiejszego filmu dźwiękowego. Stanowiąc jego główny trzon" [DM: 493]. Uwaga ta znacząca jest o tyle, o ile

26
Zob. E. Morin Kino i wyobraźnia, przeł. K. Eberhardt, PIW, Warszawa 1975, s. 197, 203.

Tamże, s. 206.

W dzienniku Irzykowskiego Dziesiąta Muza pojawiła się po swojej publikacji późno, krytyk pisał o niej w kontekście naturalizmu (zob. K. Irzykowski Dziennik, t. 2: 1916-1944, Wydawnictwo Literackie, Kraków 2001, s. 275), wzmiankował ją także w krótkim liście do Przybosia (zob. K. Irzykowski Listy 1897-1944, Wydawnictwo Literackie, Kraków 1999, s. 266).

Irzykowski zastanawiał się, czy "dźwiękowiec” jest nowym, ulepszonym teatrem [zob. DM: 469]. 
dzięki niej można sądzić, że wynalezienie „dźwiękowca” nie oznaczało dla Irzykowskiego definitywnego uśmiercenia filmu niemego, lecz raczej jego kolejne stadium rozwoju ${ }^{30}$.

Dowodem na to jest fakt, że Irzykowski nie odciął się od uczestniczenia w kulturze filmowej. Niejednokrotnie w latach 30. był zapraszany czy to na premiery filmowe, czy do składu jury oceniającego amatorskie scenariusze konkursowe, publikował pomniejsze pisma na temat kina lub udzielał wywiadów. Jednak przede wszystkim, jak wspomniał w jednej z rozmów, wciąż kino odwiedzał:

nie będąc nałogowym bywalcem kina, zaglądam do niego od czasu do czasu - i wtedy smakuje mi lepiej, nie jako ten lub ów utwór filmowy, lecz jako kino. Nie porównałbym tego jednak z odwiedzeniem dawnej kochanki - nigdy nie byłem w kinie dostatecznie zakochany. [DM: 426]

Cytat ten to wyznanie nie tyle już widza, ile obserwatora - przechodnia, który od czasu do czasu sprawdza, co dzieje się z zarzuconym przedmiotem namysłu. Nie interesują go już poszczególne filmy, lecz kierunek rozwoju kina jako medium, sytuacji kulturowej zjawiska czy wynalazku. Kino to dla niego nie film, nawet nie teoria, lecz świadectwo ważnej zmiany w kulturze, a wręcz cywilizacji - zmieniło ono kształt zarówno rynku, jak i ówczesnej publiczności. Mimo że Irzykowski nigdy nie był prawdziwym miłośnikiem filmu, kinofilem, pozostał „kulturofilem” - klerkiem bacznie rejestrującym $\mathrm{z}$ dystansu aktualne przemiany współczesności, zaabsorbowanym namysłem nad tym, co te przemiany mogły dla niej oznaczać.

\section{Co na to p. Snobkowski? - Irzykowski o widzu}

Doświadczenie i potrzeby „przeciętnego” widza zawsze stanowiły punkt wyjścia do krytyki i teorii Irzykowskiego: wcale nie zdobył Polski szturmem - film niemy nadal okazywał się zarówno bardziej opłacalny (można było wyświetlać go w wielu kinach), jak i tańszy w produkcji, ponadto większość producentów była przekonana, że ten wynalazek nie przyjmie się wśród publiczności. W rezultacie pierwszy polski "dźwiękowiec" wyemitowano dopiero w 1930 roku, a w roku 1932 w Polsce wciąż funkcjonowało około 400 kin przystosowanych wyłącznie do wyświetlania filmów niemych i 353 kina dźwiękowe - zob. T. Lubelski Historia kina polskiego. Twórcy, filmy, konteksty, Videograf II, Chorzów 2009, s. 75. 
publiczność chce w kinie dwóch rzeczy: 1) naprawdę się zabawić, w jakikolwiek sposób; 2) trochę posnobizować, tj. skonstatować, że coś jest tam a tam, przykleić na swoich wrażeniach jakąś etykietkę [...]. Ostatecznie i krytyk nic innego nie robi, ale zdaje mu się, że robi to lepiej. [DM: 371]

Do obrazu publiczności zmanipulowanej przez przemysł filmowy - i dającej się manipulować - nawiązywało krótkie opowiadanie Irzykowskiego Mój sasiad p. Snobkowski, opublikowane jako wstęp do jednej z recenzji. Rzeczony pan należał do widzów świetnie zorientowanych: „wyliczał nazwiska nie tylko pierwszorzędnych aktorów i aktorek filmowych, lecz nawet drugorzędnych" [DM: 333]. Poznał się na aktorstwie Poli Negri jak mało który krytyk, potrafił też wymienić nazwiska gwiazd, ich biografie i metryczki. Wiedzę tę czerpał z tzw. „papierowych duszków" - stworów odklejonych od afiszów i plakatów reklamujących kina na każdej ulicy i w każdym zaułku miasta, by wbić panu Snobkowskiemu do głowy: „Mary Pickford! Pick-pick i ford-ford! Pola-la-la Negri! Mia May! Douglas Fairbanks [...]. Musicie to sobie zapamiętać, panie Snobkowski, zapamiętać!" [DM: 334]. Kolejne duszki, już bardziej wyrafinowane, atakowały go z opłaconych stron czasopism branżowych jak „Ekran i Scena” czy „Film” [zob. DM: 334].

Na oczach Irzykowskiego rodził się zatem typ widza stworzonego przez przedsiębiorstwa i reklamę, których priorytetem było zarobić na swoim przemyśle. Kapitał sam wychowywał sobie konsumenta. Po pierwsze, atakował go ze wszystkich stron obrazami i nazwiskami - użyte przez Irzykowskiego onomatopeje ilustrowały swoiste „wgrywanie” tych treści w świadomość widza, natomiast metafora duszka mogła wskazywać na wrażenie braku instancji nadawczej tych informacji. Po drugie, dzięki opłaconej prasie przedsiębiorca kinowy budował sobie w oczach publiczności autorytet, jaki dawało słowo pisane wydrukowane w nowoczesnym medium, czytanym przez niemal wszystkich.

Medium to pozwalało też na przyspieszenie procesów demokratyzacji dzięki możliwości publikowania listów do redakcji13 . W takim liście można było np. nie zgodzić się z opinią poważnego i kompetentnego krytyka, co w stosunku do Irzykowskiego uczyniły anonimowe dzieci, niezgadzające się z jego recenzją filmu z Mary Pickford:

31 Pomijam tu kwestię strategii manipulowania czytelnikiem, by nie komplikować wywodu w celach reklamowych prowadzący czasopisma, poza oczywistą selekcją nadsyłanych opinii, czasami skracali notatki lub je wydłużali czy też podszywali się pod czytelników. Ta kwestia nie pojawia się w pismach Irzykowskiego. 
oburza nas bardzo recenzja pana o Sierocej doli. Ten film jest jedynie dla nas, dzieci, stworzony i dlatego tylko my możemy sądzić, czy jest dobrym, czy złym. Nas film ten bardzo wzruszył, gdyż gra Mary Pickford, która była szczera i kochana, a los jej był bardzo smutny. Zdaje się, że przy śmiechu nie zamyka się oczu, a przy płaczu ma się skrzywioną twarzyczkę. [...] O naszych filmach wolimy same pisać recenzje. [zob. DM: 401]

Tym, co szczególnie uderza w przytoczonej wypowiedzi, jest brak kompetencji nadawcy - nie musiały być nim zresztą prawdziwe dzieci, sam Irzykowski wyraził przekonanie, że to dzieło „czcigodnej mamusi” [zob.DM: 401]. Opinia o filmie Sieroca dola (reż. Paul Powell) ${ }^{32}$ opierała się nie na racjonalnej teorii i logicznych argumentach, lecz na emocjach („nas film ten bardzo wzruszył") i obiegowych opiniach - z jednej strony film był dobry, ponieważ zagrała w nim popularna aktorka, z drugiej strony nadawca odwoływał się do subiektywnego odczucia (pisał: „zdaje się") dotyczącego szczegółów okazywania emocji przez mimikę. Irzykowski z końcówki listu dowiedział się również, że dzieci same wolą pisać recenzje o filmach „naszych”, czyli „dla nas", co prowadzi do dwóch wniosków. Widz w latach 20. był już przekonany, że sam potrafi oglądać filmy i w sposób wystarczający je zaopiniować - nie potrzebował do tego krytyka. Jednocześnie miał świadomość, że film specjalizuje się na wyraźne gatunki kierowane do konkretnego odbiorcy.„Poważny pan”, jak dzieci nazwały w liście Irzykowskiego, nie powinien krytykować filmów z Mary Pickford, ewidentnie tworzonych z myślą o młodszym widzu.

Ta samodzielność niekompetentnego, nieoczytanego widza wystawionego na uliczne reklamy i czasopisma branżowe drażniła autora Dziesiątej Muzy. W wypowiedzi kończącej ripostę Irzykowski wydawał się poddawać: „pani czcigodna już zapewne wyrobiła sobie swój sąd [...] i na to już nie ma rady" [DM: 403], jednocześnie jednak dodał, że jeśli jeszcze tego nie zrobiła, to on w recenzji kolejnego filmu powie, na co powinna zwrócić uwagę na przyszłość. Występował więc także z pozycji nauczyciela - w recenzjach chciał zarysować kryteria, dzięki którym publiczność będzie mogła świadomie oglądać filmy. Z przytoczonego listu od dzieci i opowiadania o panu Snobkowskim, charakteryzującego ówczesnego przeciętnego widza, wynikałoby jednak, że jego misja zakończyła się niepowodzeniem.

Irzykowski opisał widza jako wciąż inną osobę, zmieniającą płeć, wiek, stan, ubranie, jednocześnie podkreślił, że: „mi to wszystko jedno, ja go

32 Prawdopodobnie chodziło o film w oryginale noszący tytuł Pollyanna. 
poznaję, pozostaje ze mną w tajemniczym kontakcie - nb. umysłowym" [DM: 333]. Tym samym utożsamiał się z nim, przyznawał, że nie zważał na to, kto siedział obok: kolega z redakcji, rodzina z dziećmi czy robotnik spędzający na pokazie dzień wolny. Można tu zauważyć klerkowskie zacięcie krytyka, a więc niezgodę na obniżenie wymagań wobec publiczności, nauczanie jej, a nie schlebianie gustom. Zarazem jednak Irzykowski nie mógł zaprzeczyć, że patrzył na ekran niemal z tej samej pozycji - mimo erudycji na polu literatury, nierzadko wiedział o rozwijającym się medium tyle samo, ile jego sąsiad.

\section{Krytyk filmowy - jak to powinno być zrobione?}

Irzykowski rozdzielał funkcję i rolę krytyka i recenzenta, pisząc: „recenzja - to najpospolitsza postać tej przystosowalności do potrzeb społecznych. Rozleniwia ona krytyka swą gotową, wygodną formą [...]. Ale krytyka może istnieć w różnych stopniach i formach natężenia"33. Krytyka to coś więcej niż recenzja, będąca tylko jedną z możliwości działania pisarza. Jednocześnie warto zauważyć, że Irzykowski „czytał po prostu filmy tak, jak się czyta dzieło literackie"34 - warto zapytać jednak, czy była to świadoma strategia autora Pałuby, czy mechaniczne przeniesienie na inne medium przyzwyczajeń krytyka literackiego.

Irzykowski nawoływał więc z pozycji, jak sam pisał, , attaché starego państwa Literatury":

podnoszę, aby jeszcze po raz setny stwierdzić to, co w swojej książce udowodniłem, że głównym czynnikiem w filmie jest nie aktor, nie reżyser, nie fabrykant - lecz autor, literat, poeta - nie jako zawodowiec, lecz jako ten, co ma pomysły [...]. Bo na początku wszelkiej sztuki, także filmowej, jest wyobraźnia. [DM: 343-344]

Postulat, by dowartościować twórcę fabuły, wpisuje się w kluczową myśl zawartą w książce Walka o treść. Zachwyt awangardy nad teorią fotogenii i skupienie się na możliwościach technicznych filmu nie spotkały się z aprobatą Irzykowskiego [zob. DM: 138, 297]. Według niego prawdziwy twórca filmowy odpowiadać miał za treść, sens, ideę - tworzyć nowe wartości,

33 K. Irzykowski Słoń wśród porcelany. Lżejszy kaliber, Wydawnictwo Literackie, Kraków 1976, S. 221-222. 
czyli „wynalazki”35. Istniała jednak różnica między tak pojętą rolą scenarzysty a rolą pisarza - literat wydzierał pojęcia z rzeczywistości „wewnętrznej”, duchowej, natomiast twórcę filmowego zajmowało obcowanie z materią, aktualność rzeczywistości „zewnętrznej”. Irzykowski postulował, by pokazywać w zaskakujący sposób to, co znamy z codziennego życia, jak bójki, pocałunki, zmaganie z otaczającymi nas sprzętami czy wreszcie przyrodą. Tym m.in. nazywał ruch w kinie.

Drugim powodem, dla którego to właśnie scenarzysta miał zająć główne miejsce wśród twórców filmowych, mógł być sam kształt, formuła większości ówczesnych filmów popularnych. Amerykańskie komedie czy filmy fantastyczne i sensacyjne na początku lat 20., czyli w okresie pracy nad Dziesiąta Muza, zazwyczaj składały się z niepowiązanych ze sobą pomysłowych scenek czy gagów. Fabuła często nie przedstawiała konkretnych wydarzeń mających doprowadzić do spójnego finału lub przemiany bohatera. Wciąż w 1924 i 1925 roku w wielu filmach, szczególnie komediowych, ważniejsza była koncepcja czy to postaci, jak w przypadku trampa Charliego, czy sytuacji, jak w filmie Zamek duchów Abla Gance'a. Zdarzało się również, że bazowały na sprawdzonej formule, jak te z Busterem Keatonem - Rozkosze gościnności i Sherlock Holmes Junior kończyły się widowiskowym pościgiem. Irzykowski w jednej z recenzji zachwycił się hollywoodzkim pomysłem stworzenia stanowiska "gagmana", czyli „literata”, jak sam to zdefiniował, który wymyślał twórcom filmowym nowe kawały [zob. DM: 343]. Według niego oznaczałoby to krystalizowanie się w medium - wymagającym współpracy wielu wyspecjalizowanych osób indywidualności odpowiedzialnej za treść konkretnego dzieła. Literat dawał czytelnikowi pojęcia, ramy, kontury, natomiast scenarzysta musiał zarysować fabułę, a następnie przekształcić ją na papierze w konkretny obraz.

Według Irzykowskiego poszukiwanie dobrych tematów dla kina w dziełach literackich nie sprawdziło się. Była to ważna kwestia w namyśle nad filmem polskim w całym dwudziestoleciu, wielu krytyków podnosiło ją zarówno w kontekście formy i jakości filmu, jak i kwestii pedagogicznych ${ }^{36}$. Jednego z głównych celów wychowawczych kina upatrywano w popularyzacji wielkich

Zob. K. Irzykowski Walka o treść..., s. 212.

W 1939 roku Jerzy Bossak dobitnie pisał o klęsce adaptacji wielkiej literatury polskiej i jej roli edukacyjnej, połączył również kwestię wychowawczą z formalną - zob. J. Bossak Mniszkówna... i co dalej?, w: Mniszkówna... i co dalej w polskim kinie? Wybór tekstów z czasopism filmowych dwudziestolecia międzywojennego, oprac. B. Gierszewska, Wydawnictwo Akademii Świętokrzyskiej, Kielce 2001, s. 60. 
dzieł literatury - skrócone i uproszczone miały trafiać do masowej publiczności ${ }^{37}$. Irzykowskiemu oczywiście to nie wystarczało: z jednej strony ganił w swoich recenzjach zbyt wierne kopiowanie fabuły czy akcji książki, z drugiej ubolewał nad pomijaniem ważnych dla treści myśli zawartych w klasycznej literaturze stanowiącej próbę opisania skomplikowanych zjawisk ludzkiej psychiki - nie wierzył, by ich przełożenie na obraz filmowy było możliwe. Często wśród reżyserów pojawiała się tendencja do „bezmyślnego odtwarzania obrazów" [DM: 346]. Film taki nudził, bo nie miał w sobie estetycznego czy poznawczego pierwiastka, obrazy posuwały wydarzenia naprzód, nie miały wartości jako całość - były po prostu ilustracją książki. Irzykowski pisał o tym w recenzji Czterech jeźdźców apokalipsy: „bestie apokaliptyczne wprowadza się za wcześnie, nie w związku z życiem, lecz przede wszystkim jako postacie książkowe, jako ilustracje do wywodów rosyjskiego mistyka" [DM: 280-281]. Lepiej poszukiwać inspiracji w codziennym życiu otaczającym człowieka, ale też w prostej fabule. Irzykowski zauważył, że „gorsza literatura staje się najlepszym filmem" [DM: 420]. Pisał, jak się wydaje, poważnie, żeby wydobyć dla filmu Rodziewiczównę i jej „świat polskich włóczęgów, dziadów, bałagułów, ekonomów, karczmarzy, gajowych itd." [DM: 332]

W poszukiwaniu dobrego filmu polskiego krytyk nie tropił za wszelką cenę oznak artyzmu obejrzanych produkcji, nie próbował dopasować bieżącego rynku do własnych metod, lecz uważnie obserwował rzeczywistość kina i na tej podstawie starał się określić, co będzie dla niego najlepsze. Jego istotą w II Rzeczypospolitej powinna być nie artystyczność rozumiana według starych kanonów, lecz zupełnie nowa kategoria, swoistość medium, czyli "kinowość"38. Dzięki analizie recenzji Irzykowskiego można wyodrębnić kilka przykładów prawdziwie kinowych tematów, m.in. motyw kolejowy, „ciałowość", czyli walkę z własnym i obcym ciałem, w odróżnieniu od erotycznej cielesności, tłumy czy pojedynki. Wszystkie realizują nadrzędną myśl zawartą w Dziesiątej Muzie, a więc są ucztą dla oka, pokazują człowieka uwikłanego w jakiś rodzaj relacji z materią, stanowią realizację "prawa zwierciadła”, czyli zarówno epistemologiczną stronę chęci widzenia, jak i „kolekcjonerską" chęć oglądania i podglądania, charakterystyczną dla kultury popularnej ${ }^{39}$.

37 Przykładem są masowe produkcje oparte na kanwie prozy Zapolskiej, Żeromskiego, Wyspiańskiego czy Sienkiewicza.

Szerzej tą kategorią zajmowała się Elizabeth Nazarian.

39 Wedle "prawa zwierciadła” wyłożonego w Dziesiątej Muzie film wychodzi naprzeciw chęci człowieka, by oglądać rzeczy i sprawy oderwane od rzeczywistości, by móc je widzieć, a więc wziąć 
Opracowanie tych tematów należało już jednak do zadań reżysera - drugiego ważnego współautora filmu $u^{40}$ - który mógł wykorzystywać tę teorię do wpływania na reakcję publiczności i wydobywanie znaczenia z omówionych tu pomysłów lub tematów „kinowych”.

Wiele filmów tamtego okresu skupiało się na tym, by pokazać widzowi cuda świata, którego nie mógł samodzielnie doświadczyć - egzotyczne krainy, tubylców, florę i faunę. Możliwości techniczne pozwalały na wyemitowanie w jednym ujęciu wielkich skupisk ludzkich - tłumów czy panoram metropolii. Dla krytyka było to istne „optyczne pandemonium" [zob. DM: 188] oraz „świetność optyczna codzienności” [zob. DM: 375]. Zwykłe życie, odbite na ekranie, nabierało cech cudowności. Jednak Irzykowski nie chciał ograniczać roli kina do wpisanej w to medium bezpośredniości doświadczenia, jego „zmysłowości”. Chociaż pisał wprost, że kino było zbyt oczywiste i bezpośrednie, więc nie oddziaływało na wyobraźnię tak jak poezja, to jednak dodawał, że w takim razie musiało „używać specjalnych środków, aby w świat wyobraźni powrócić" [DM: 315]. Można więc stworzyć na ekranie ucztę dla „oczu wyobraźni" widza. W tym celu reżyser powinien mieć repertuar dobrze dobranych narzędzi, m.in. montaż, napisy czy aktora. O tych środkach Irzykowski pisał w recenzjach najwięcej, choć pojawiały się też inne - przykładowo rozwijająca się technologia (barwa, później dźwięk), a nawet manipulacje czasem filmu i w filmie ${ }^{41}$.

w posiadanie, zatopić się w fikcji emitowanych na ekranie widm [zob. DM: 37-39]. Gołębiewska sięgała głębiej w tę teorię i odnajdywała tam ważny składnik reprodukcyjny, naśladowczy względem cech poznawczych ludzkiej percepcji, inspirowany filozofią Henriego Bergsona zob. M. Gołębiewska Irzykowski. Rzeczywistość i przedstawienie, s. 199-200. Natomiast Nazarian upatrywała w „prawie zwierciadła” diagnozy narodzin nowej percepcji widza kinowego - zob. E. Nazarian The Tenth Muse..., s. 115. Koresponduje ono także z teorią Béli Balázsa, który swojego Człowieka widzialnego opublikował w tym samym roku, w którym ukazała się Dziesiąta Muza. Węgierski filmowiec widziałby w narodzinach kina powrót kultury wizualnej, lecz jednocześnie pojawienie się nowego typu odbiorcy, człowieka odznaczającego się „nową wrażliwością, nową zdolnością i nową kulturą" - B. Balázs Wybór pism, wyb. A. Jackiewicz, przeł. K. Jung, R. Porges, Wydawnictwo Artystyczne i Filmowe, Warszawa 1987, s. 48.

40 Wbrew przekonaniu Kumora, który twierdził, że Irzykowski do reżyserów odnosił się z pogardą - zob. A. Kumor Karol Irzykowski. Teoretyk filmu, s. 208. Wydaje się, że krytykowi nie podobał się raczej aktualny stan reżyserii, nie reżyseria jako taka. Do myśli, że reżyser może być autorem filmu, zapewne zainspirowały go rozważania Słonimskiego - zob. A. Słonimski Romans zX Muzą. Teksty filmowe z lat 1917-1976, wyb., wstęp i oprac. M. i M. Hendrykowscy, Biblioteka "Więzi", Warszawa 2007, s. 64.

41 "Czas to wrażenie swobody i wytchnienia. W filmach europejskich czas mierzy się nerwowo, na minuty i sekundy, w filmach amerykańskich [...] na dni i miesiące, a mimo to nie jest nudny" 
Przykładowo jednym z narzędzi reżysera była mimika aktorów, lecz jako najbliższa słowa, ilustrowała jedynie treść napisów, więc zbliżenia na twarz nie podobały się Irzykowskiemu [zob. DM: 205]. Krytyk dużo bardziej cenił gest, w którym widział źródło komizmu i tragizmu: „komizm występuje dopiero w nerwowym drganiu skradających się palców" [DM: 303]. Co ciekawe, dopuszczał myślenie o mimice jako rzeczy najważniejszej w kinie, ale tylko u tych reżyserów, którzy na ekranie przedstawialiby swoiste studium z natury, traktowaliby zestawy min jak wynalazki i pokazywali je na nowo [zob. DM: 300].Zaadaptowanie słów opisujących stany emocjonalne i próba pokazania ich bezpośrednio przełożonych na ekran skutkowały przeciążeniem obrazu patosem i sztucznością. Według Irzykowskiego aktor powinien być przede wszystkim charakterystyczny, czyli wykorzystywać to, co miał przyrodzone, np. charakterystyczną cechę ciała - jak tusza słynnego komika Fatty'ego czy wykreowana persona trampa Charliego.

Warto dodać, że aktor był nie tylko „narzędziem” reżysera. W Dziesiątej Muzie Irzykowski pisał, że należą mu się laury autora, kiedy „ustala raz na zawsze ostateczną postać sztuki, wykańcza jej powierzchnię, a więc nieraz szczegóły rozstrzygające" [DM: 210]. Jeśli więc dotychczas nie zostały wypracowane i ustalone kryteria tworzenia filmów $\mathrm{i}$ ich oceniania, aktor pozostawał jedynym spoiwem całości dzieła lub produktu - trzecim autorem filmu.

W swoim „poradniku filmowym” Irzykowski nie przeoczył także samych krytyków - zwracał się do piszących o kinie z własnymi propozycjami dotyczącymi języka kształtującej się gałęzi krytyki. Zdawał sobie sprawę, że w obecnych czasach o filmach trzeba pisać , jako o produktach pewnego przemysłu quasi-artystycznego, który zaspokaja pewne potrzeby wizualne" [DM: 349]. Jednocześnie - jako klerk, obrońca tradycyjnych wartości - próbował ocalać przekonanie, że film może być prawdziwą sztuką, a więc tworzoną przez indywidualność, szczerą i kreującą nowe treści w kulturze ${ }^{42}$.

Recenzje Irzykowskiego powstały z wiary we wzrost poziomu rodzimej kinematografii (również swoją książkę napisał w tym właśnie celu [zob. DM:

[DM: 332]. Wnioski te ciekawie korespondują z tezami cenionego przez Irzykowskiego Tadeusza Peipera, który na łamach „Zwrotnicy” pisał o ruchu jako trwaniu: „spoczynek (lub ruch powolny) może być użyty jako środek natężenia wrażenia ruchu, poprzedzającego spoczynek lub następującego po nim" - T. Peiper O statyzmie, w: Polska myśl filmowa. Antologia tekstów z lat 1898-1939, oprac. J. Bocheńska, Ossolineum, Wrocław-Warszawa-Kraków 1975, s. 116. 
7]), tak więc wpisywały się zarówno w toczącą się walkę o polski film dojrzały artystycznie ${ }^{43}$, jak i w dyskusję o wpływie i funkcjonowaniu kina w życiu społecznym ${ }^{44}$. Dlatego autor Dziesiątej Muzy musiał poniekąd porzucić rolę krytyki jako „poznania prawdy o dziele i autorze"45 na rzecz funkcji recenzenckich, czyli informowania widza o stanie kinematografii i wykształcania w nim umiejętności oglądania filmów oraz użytecznej dla widza ich oceny.

Trzeba jednak pamiętać, że Irzykowski próbował w recenzjach znaleźć potwierdzenie wcześniejszych intuicji, przeforsować własne pomysły dzięki perswazyjnej roli języka krytyki rozumianej jako walka czy gra ${ }^{46}$. Niekiedy zaciekle bronił swoich postulatów, ale niewątpliwie musiał je też weryfikować, czasami uzgadniać własne metody i intuicje z rozwijającą się wbrew nim rzeczywistością. Próbował więc dopasować się do nowego świata, jednocześnie nie porzucając własnej osobowości. Dlatego, odpowiadając na postawione wcześniej pytanie o „literackim” czytaniu filmów przez autora Dziesiątej Muzy, Irzykowskiego bez wątpienia można nazwać krytykiem filmowym, kształtującym i poprawiającym świat kultury. Było to również kolejne jego oblicze recenzenta bieżącego repertuaru, nie tyle zdobywającego wiedzę o medium, ile uczącego się wraz z jego powstawaniem.

Zob. B. Gierszewska Wstęp, w: Mniszkówna... i co dalej?, s. 13.

Zob. J. Bocheńska Polska myśl filmowa..., s. 7. wersytetu Śląskiego, Katowice 2005, s. 9. 


\section{Abstract}

\section{Weronika Szulik}

UNIVERSITY OF WARSAW

"Once I Went to the Cinema...": Karol Irzykowski and Popular Film in the 1920s

The article presents Karol Irzykowski's film theory as seen from the perspective of a viewer and participant of the newly emerging visual culture. Until now scholars have only treated Irzykowski as a pioneer of Polish film theory, but Szulik now portrays him as a regular at film screenings as well as an active reviewer of the cinematic repertory of his day. She draws on Irzykowski's reviews in Wiadomości Literackie (1924-1925) in order to show that his theory was rooted in his participation in and reflection on popular culture.

\section{Keywords}

Karol Irzykowski, Wiadomości Literackie, Dziesiq̨ta Muza [The Tenth Muse], silent film 